\title{
Major histocompatibility complex class II antigen expression in B and T cell non-Hodgkin's lymphoma
}

\author{
M E F SMITH, C S HOLGATE, J M S WILLIAMSON, I GRIGOR, P QUIRKE, \\ C C BIRD
}

From the Department of Pathology, University of Leeds, Leeds

SUMMARY An immunohistochemical study of $46 \mathrm{~B}$ and T cell non-Hodgkin's lymphomas, using monoclonal antibodies to the products of the major histocompatibility complex (MHC) class II antigen subregions, DP, DQ, and DR, showed that most B and T cell lymphomas express these antigens. Both coordinate and non-coordinate expression of MHC class II antigens was observed, but this did not correlate with immunological phenotype, morphological grade, or proliferation index as determined by flow cytometry.

Class II major histocompatibility complex (MHC) antigens are heterodimeric glycoproteins composed of $\alpha$ and $\beta$ subunits and are encoded by three subregions, DP, DQ, and $D R$ in the $D$ region of the MHC on chromosome 6. They are expressed predominantly on B lymphocytes, activated T lymphocytes, histiocytes and vascular endothelium. B lymphocytes show coordinate expression of DP, DQ, and DR products. ${ }^{1}$ MHC class II antigens are thought to have important functions in the interactions between lymphocytes and in antigen presentation to lymphocytes by macrophages.

It has been suggested that MHC class II antigen expression in leukaemic cells may be related to cellular differentiation. ${ }^{2}$ B cell non-Hodgkin's lymphoma may show either coordinate or non-coordinate expression of MHC class II subregion products, and it has been suggested that within $B$ cell nonHodgkin's lymphoma antigen expression may be related to cellular proliferation. ${ }^{34}$

The aims of this study were to document MHC class II DP, DQ, and DR expression in $B$ and $T$ cell non-Hodgkin's lymphoma and to relate this expression to an index of cellular proliferation measured by flow cytometry.

\section{Material and methods}

\section{TISSUES}

Forty six biopsy specimens from 45 patients with non-Hodgkin's lymphoma were studied (table 1).

Accepted for publication 17 July 1986
Cases 3, 11, and 12 were of spleen, 4 and 31 of tonsil, 14 of palate, 20 of submandibular salivary gland, and 44 and 45 of skin. The remainder were lymph nodes. Case 32 was from the same subject as biopsy 26 but taken 40 months later. Portions of each specimen were snap frozen in liquid nitrogen and the remainder fixed in $10 \%$ formalin and routinely processed to paraffin.

\section{IMMUNOHISTOCHEMISTRY}

An indirect immunoperoxidase technique was used on frozen sections $8 \mu \mathrm{m}$ thick. ${ }^{5}$ Table 2 lists the monoclonal antibodies used. In addition to those directed against MHC antigens, monoclonal antibodies directed against a wide range of $B$ and $T$ lymphocyte surface membrane antigens were applied to phenotype tumours. Skin sections were incubated with the primary antibody overnight. Other sections were incubated with the primary antibody for one hour. All monoclonal antibodies were used at optimal dilutions derived from titration studies performed on frozen sections of fresh tonsil.

Each MHC class II antigen immunoperoxidase preparation was assessed by a standard procedure. The percentage of positive staining cells was assessed visually and each case was assigned to one of the following grades: grade $0(0-<5 \%$ cells positive); grade 1 ( $5-<25 \%$ cells positive); grade $2(25-<50 \%$ cells positive); grade 3 ( $50-<75 \%$ cells positive); grade 4 ( $75-100 \%$ cells positive).

Staining of less than $50 \%$ of cells (grades 0,1 , and 2) was considered to indicate significantly "reduced expression" of MHC class II antigens, and staining of more than $50 \%$ of cells (grades 3 and 4), "strong 
Table 1 MHC class II antigen expression in relation to lymphoma subtype, DNA ploidy level, and proliferation index

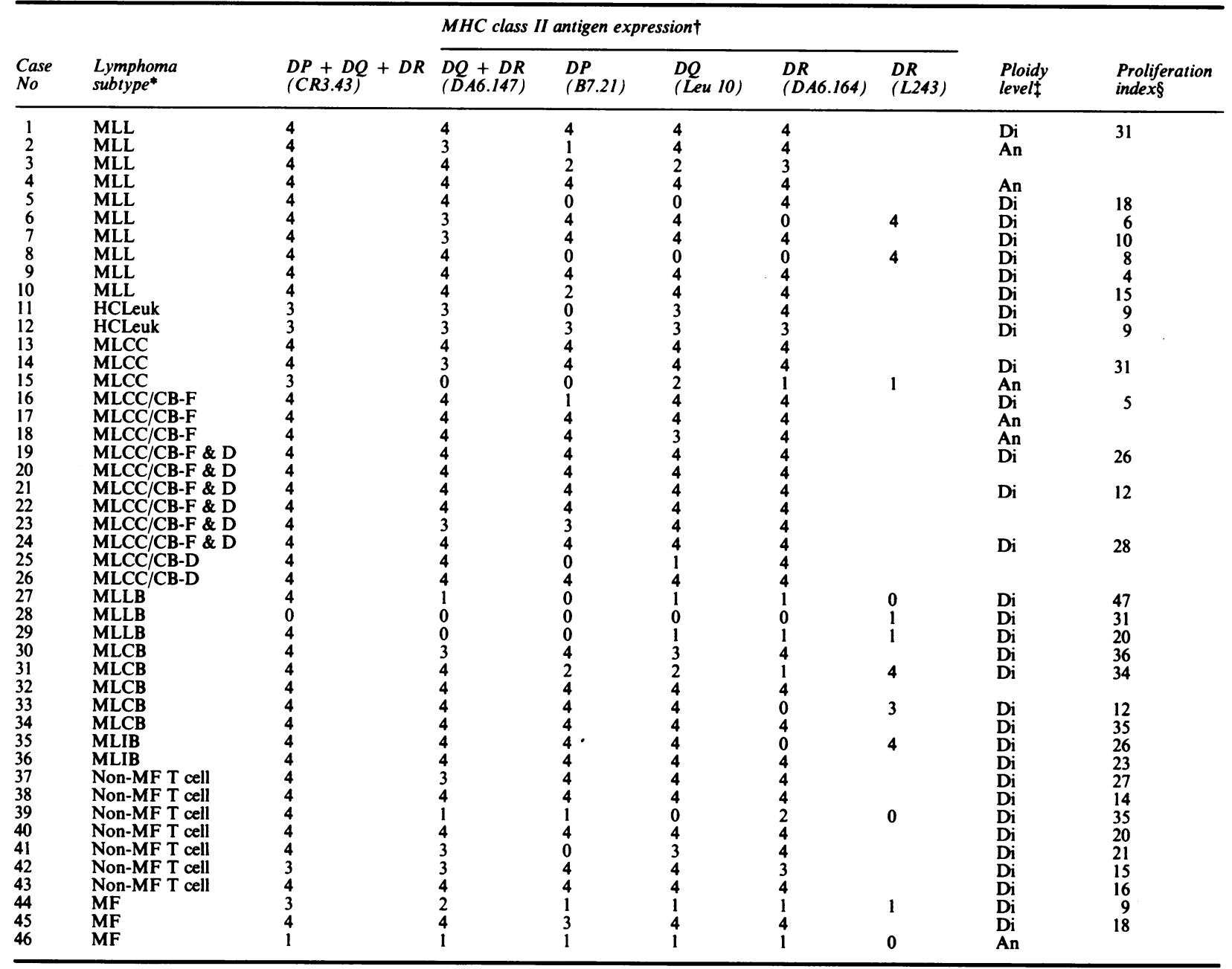

${ }^{*} \mathrm{MLL}=$ malignant lymphoma lymphocytic; HCLeuk = hairy cell leukaemia; $\mathrm{MLCC}=$ malignant lymphoma centrocytic; MLCC/CB = malignant lymphoma centrocytic/centroblastic; $F=$ follicular; $D=$ diffuse; $M L L B=$ malignant lymphoma lymphoblastic; $M L C B=$ malignant lymphoma centroblastic; MLIB = malignant lymphoma immunoblastic; non-MF T cell = non-mycosis fungoides $\mathrm{T}$ cell lymphoma; $\mathrm{MF}=$ mycosis fungoides. tGrade $0=\langle 5 \%, 1=5$ to $<25 \%, 2=25$ to $<50 \%, 3=50$ to $<75 \%, 4=75$ to $100 \%$ of positively staining cells.

tPloidy level: $\mathrm{Di}=\mathrm{DNA}$ diploid, An = DNA aneuploid: Eight cases not studied; four insufficient material; four large (>15\%) coefficient of variation. $\S$ Proliferation index $=\%$ cells in $\mathbf{S}$ and $\mathbf{G}_{2}$ phase.

expression." Coordinate expression of MHC class II antigens was defined as strong expression of all three subregion products and non-coordinate expression as reduced expression of one or more subregion products.

\section{LYMPHOMA CLASSIFICATION}

Tumours were assigned to the $\mathrm{B}$ or $\mathrm{T}$ cell lineage on the basis of the surface membrane immunophenotype. ${ }^{5}$ Lymphomas of B cell phenotype were classified morphologically according to the Kiel classification. ${ }^{12}$ Lymphomas of $\mathrm{T}$ cell phenotype were classified either as mycosis fungoides or non-mycotic $\mathrm{T}$ cell lymphomas.

\section{FLOW CYTOMETRY}

Nuclear DNA measurements were performed as previously described, ${ }^{13}$ using a modification of the method of Hedley et al. ${ }^{14}$ Briefly, $30 \mu \mathrm{m}$ sections of routinely processed paraffin embedded tissue were dewaxed in xylene and rehydrated by passing through a series of graded alcohols. The tissue was washed in distilled water, digested by pepsin (Sigma), stained with a $1 \mu \mathrm{g} / \mathrm{ml}$ solution of $4^{\prime}, 6^{\prime}$-diamidino-2- 
Table 2 Specificity and source of monoclonal antibodies

\begin{tabular}{|c|c|c|c|}
\hline Antibody & Specificity & Allotype restriction & Source \\
\hline $\begin{array}{l}\text { CR3.43 } \\
\text { DA6.147 } \\
\text { B7/21 } \\
\text { Leu } 10 \\
\text { DA6.164 } \\
\text { L243* } \\
\text { Anti-IgM } \\
\text { Anti-IgD } \\
\text { Anti-IgG } \\
\text { Anti-IgA } \\
\text { Anti- } K \\
\text { Anti- } \lambda \\
\text { OKT4 } \\
\text { OKT8 } \\
\text { T6 } \\
\text { OKT11 } \\
\text { UCHT-1 }\end{array}$ & $\begin{array}{l}\text { MHC class II, DP }+\mathrm{DQ}^{+}+\mathrm{DR}^{6} \\
\text { MHC class II, DR }+\mathrm{DQ}^{7} \\
\text { MHC class II, DP } \\
\text { MHC class II, DQ9 } \\
\text { MHC class II, DR }{ }^{10} \\
\text { MHC class II, DR }{ }^{911} \\
\text { IgM heavy chain } \\
\text { IgD heavy chain } \\
\text { IgG heavy chain } \\
\text { IgA heavy chain } \\
\kappa \text { light chain } \\
\lambda \text { light chain } \\
\text { Helper/inducer T cell (CD4) } \\
\text { Suppressor/cytotoxic T cell (CD8) } \\
\text { Common thymocyte antigen (CD1) } \\
\text { Pan T cell (CD2) } \\
\text { Mature T cell (CD3) }\end{array}$ & $\begin{array}{l}\text { None } \\
\text { None } \\
\text { None } \\
\text { DR3, DR7 } \\
\text { DR7 } \\
\text { None }\end{array}$ & $\begin{array}{l}\text { CM Steel } \\
\text { CM Steel } \\
\text { CM Steel } \\
\text { Becton Dickinson } \\
\text { CM Steel } \\
\text { Becton Dickinson } \\
\text { Unipath } \\
\text { Unipath } \\
\text { Unipath } \\
\text { Bethesda Research Laboratories } \\
\text { Unipath } \\
\text { Unitpath } \\
\text { Ortho Diagnostics } \\
\text { Ortho Diagnostics } \\
\text { Coulter Electronics } \\
\text { Ortho Diagnostics } \\
\text { Unipath }\end{array}$ \\
\hline
\end{tabular}

*Used only in cases in which DA6.164 stained less than $50 \%$ of cells.

phenylindole dihydrochloride (Boehringer Mannheim, West Germany), filtered and syringed. Samples containing 10000 nuclei were analysed by an EPICS V flow cytometer (Coulter Electronics, Hialeh, Florida, United States). For excitation, a Coherent Innova-90 5W UV enhanced argon ion laser was used at $50 \mathrm{~mW}$, at a wavelength of $350 \mathrm{~nm}$. A $408 \mathrm{~nm}$ interference filter removed incident scattered fluorescence.

DNA aneuploidy was defined as the presence of more than one $G_{0} / G_{1}$ peak. ${ }^{15}$ Cell cycle analysis was performed in diploid tumours using the method of Bagwell et al. ${ }^{16}$ The percentage of cells in the $S$ and $\mathrm{G}_{2}$ compartments were combined to give a prolifer- ation index. Cell cycle analysis was not performed in DNA aneuploid tumours due to overlap of cell populations. A standard programme (Coulter Electronics, Hialeh, Florida, United States) was used to calculate the half peak coefficient of variation of the $G_{0} / G_{1}$ peak in diploid cases.

\section{Results}

Immunostaining with standard lymphoma markers showed that 36 non-Hodgkin's lymphoma were of B cell and 10 of $T$ cell phenotype (table 1). Equal numbers of B cell tumours exhibited $\kappa$ and $\lambda$ light chain

Table 3 Pattern of MHC class II antigen expression

\begin{tabular}{|c|c|c|c|c|}
\hline Lymphoma subtype* & $\begin{array}{l}D R \\
(D A 6.164 \text { or } L 243)^{*}\end{array}$ & $\begin{array}{l}D Q \\
(\text { Leu 10) }\end{array}$ & $\begin{array}{l}D P \\
(B 7 / 21)\end{array}$ & No of cases \\
\hline \multicolumn{5}{|l|}{ B cell lymphoma: } \\
\hline \multirow[t]{3}{*}{ Malignant lymphoma lymphocytic } & + & + & + & 5 \\
\hline & + & + & - & 2 \\
\hline & + & - & - & 3 \\
\hline \multirow{2}{*}{ Hairy cell leukaemia } & + & + & + & 1 \\
\hline & + & + & - & 1 \\
\hline \multirow{2}{*}{ Malignant lymphoma centrocytic } & + & + & + & 2 \\
\hline & - & - & - & 1 \\
\hline \multirow[t]{3}{*}{ Malignant lymphoma centrocytic/centroblastic } & + & + & + & 9 \\
\hline & + & + & - & 1 \\
\hline & + & - & - & 1 \\
\hline \multirow{2}{*}{ Malignant lymphoma centroblastic } & - & - & - & 3 \\
\hline & + & + & + & 4 \\
\hline & + & - & - & 1 \\
\hline \multirow{4}{*}{$\begin{array}{l}\text { Malignant lymphoma immunoblastic } \\
T \text { cell lyphoma: } \\
\text { Non-mycosis fungoides } T \text { cell lymphoma }\end{array}$} & + & + & + & 2 \\
\hline & + & + & + & 5 \\
\hline & + & + & - & 1 \\
\hline & - & - & - & 1 \\
\hline \multirow[t]{2}{*}{ Mycosis fungoides } & + & + & + & 1 \\
\hline & - & - & - & $\begin{array}{r}2 \\
46\end{array}$ \\
\hline
\end{tabular}

* + grade 3 and $4 ;-=$ grade 0,1 and 2 .

DR grade = DA6.164 grade, unless L243 grade was higher. 


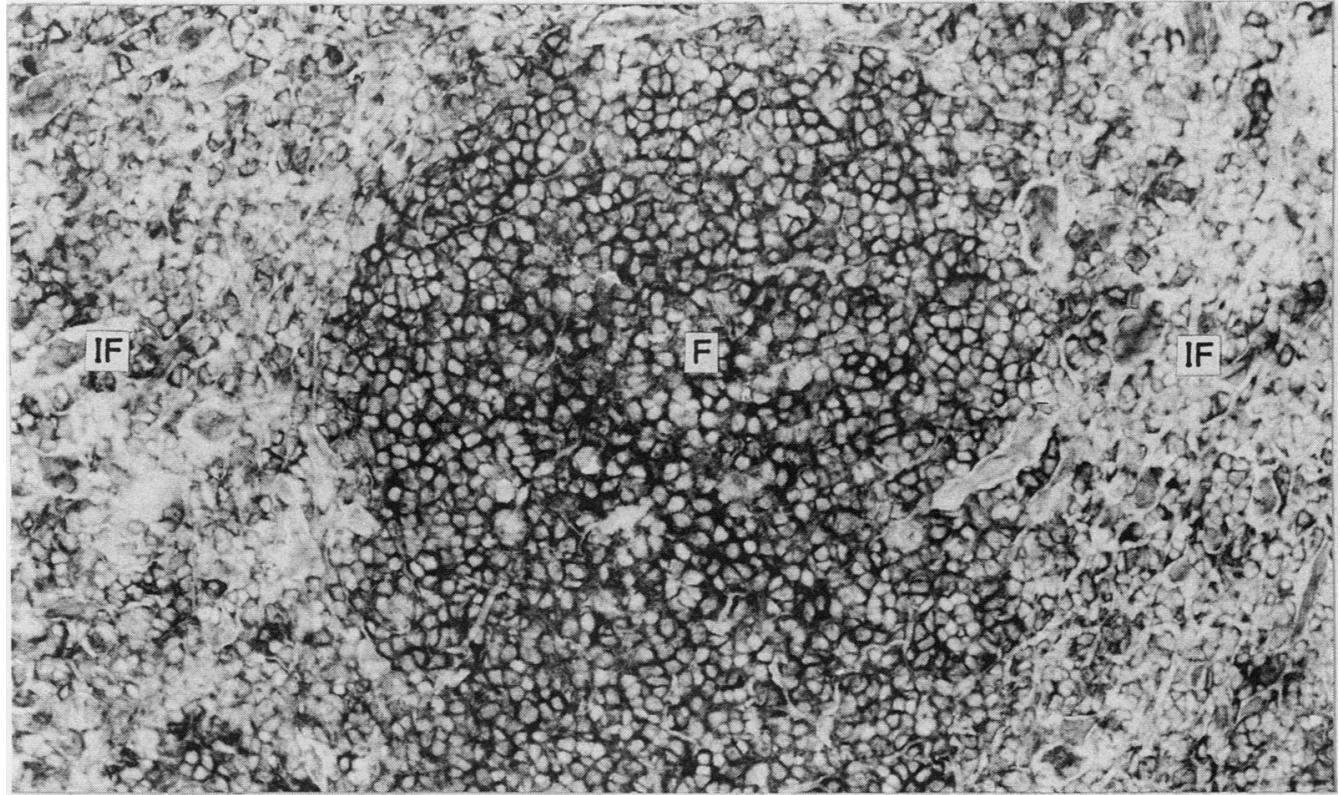

Fig 1 Case 21 (MLCC/CB-F and D) stained by Leu 10. Note strong $D Q$ antigen expression by most cells within neoplastic follicle $(F)$ and weaker expression and sometimes absence of expression by interfollicular $(I F)$ cells. (Immunoperoxidase.)

restriction. Twenty six B cell non-Hodgkin's lymphoma were of low grade morphology and 10 of high grade. Three of the $10 \mathrm{~T}$ cell non-Hodgkin's lymphoma were of mycosis fungoides type. None of the remaining $\mathrm{T}$ cell lymphomas expressed the cortical

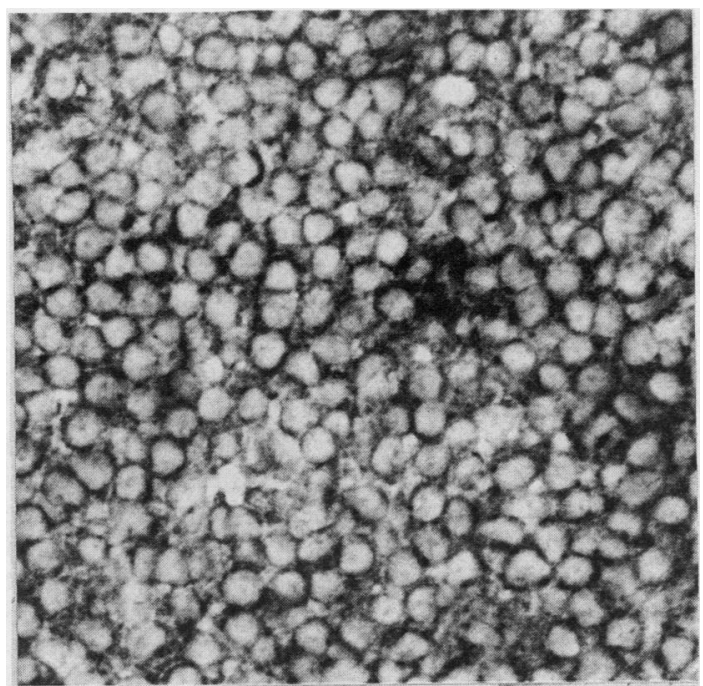

Fig 2 Case 40 (non-mycosis fungoides $T$ cell) stained by $B 7 / 21$. Note strong expression of DP antigen by tumour cells. (Immunoperoxidase.) thymocyte antigen (T6).

MHC CLASS II ANTIGEN IMMUNOHISTOCHEMISTRY Table 1 shows the MHC class II antigen expression of each lymphoma and table 3 the different patterns of expression within the various lymphoma subtypes. All but one B cell and one T cell non-Hodgkin's lymphoma expressed MHC class II antigens when stained by CR 3.43, which recognises DP, DQ, and DR products.

Thirteen of $36 \mathrm{~B}$ cell and four of $10 \mathrm{~T}$ cell lymphomas showed non-coordinate expression of DP, DQ, and DR products. Similar proportions of $\kappa$ phenotype (seven of 18 cases) and $\lambda$ phenotype (six of 18 cases) B cell lymphomas showed non-coordinate expression. Cases showing non-coordinate expression occurred in every lymphoma subtype apart from malignant lymphoma immunoblastic, of which there were only two examples. Non-coordinate expression was most common in malignant lymphoma lymphocytic (five of 10 cases), malignant lymphoma lymphoblastic (three of three cases) and mycosis fungoides (two of three cases). There was reduced expression of DP antigen in 17 cases, DQ antigen in 12, and DR antigen in six. All cases showing reduced DR expression also showed reduced DQ and DP expression, and all cases showing reduced DQ expression also showed reduced DP expression. Some cases showed reduced expression of DP alone (table 3). 


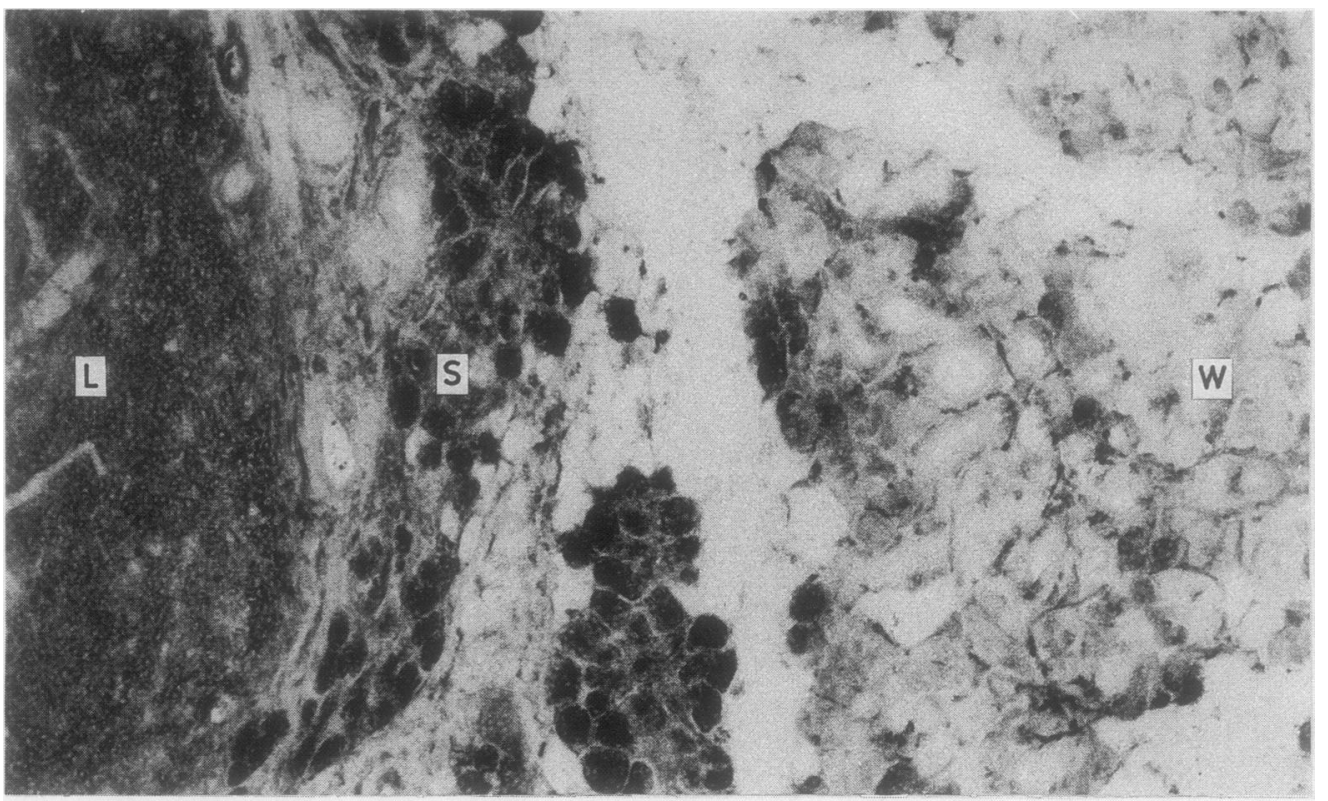

Fig 3 Case 20 (MLCC/CB-F and D) stained by Leu 10. Note strong expression of DQ antigen by lymphoma (L), very strong expression in epithelial acini $(S)$ adjacent to lymphomas, and variable but generally weaker expression of acini $(W)$ distant from lymphoma. (Immunoperoxidase.)

\section{PATTERN OF IMMUNOSTAINING}

Figs 1 and 2 show the pattern of immunostaining of B and $T$ cell lymphomas. In general, tumour cells with large quantities of cytoplasm showed both surface membrane and cytoplasmic antigen staining, whereas those with scanty cytoplasm seemed to show only membrane staining. The cytoplasm of vascular endothelium in many lymphomas also strongly expressed MHC class II antigens, as did the processes of dendritic cells in all lymphoma subtypes.

All 10 lymphocytic lymphomas contained variably sized nodules in which cells strongly expressed MHC class II antigens. In preparations showing reduced MHC class II antigen expression staining was mainly confined to the nodules. Comparison with sections stained with haematoxylin and eosin showed that these nodules represent the proliferation centres observed in such tumours. ${ }^{17}$ In eight of the nine lymphomas with follicular components most cells within neoplastic follicles exhibited intense expression of all MHC class II subregion products, with absent or weak expression in interfollicular cells (fig 1). In some cases staining was accentuated at the periphery of follicles, possibly in the region of lymphocytic mantles. In a submandibular salivary gland, partially replaced by a centroblastic/centrocytic follicular and diffuse lymphoma (case 20), epithelial acini near the lymphoma showed very strong cytoplasmic staining with all MHC class II antigen antibodies, while more distant acini showed staining of variable but decreased intensity (fig 3). The salivary gland showed no evidence of autoimmune disease.

Cells expressing MHC class II antigens were diffusely distributed within the $\mathrm{T}$ cell lymphomas. MHC class II antigen expression was confined to a prominent mesh of dendritic cells and their processes in a lymph node affected by mycosis fungoides (case 46). The intervening tumour cells, the major component, showed no staining.

\section{FLOW CYTOMETRY}

DNA aneuploidy was shown in six lymphomas, five of which were of $B$ cell type and one of $T$ cell type. Several patterns of MHC class II antigen expression were present among these cases (table 1).

The mean coefficient of variation of the $\mathbf{3 2}$ diploid cases was $8.7 \%$. Table 1 documents the proliferation indices (percentage of cells in $S$ and $G_{2}$ phase) of these cases. When the proliferation index was plotted against percentage of DP positive cells (fig 4) no direct relation was observed. Indeed, some tumours with no detectable DP expression had high proliferation indices, and the converse was also true. Plotting proliferation index against $D Q$ and $D R$ expression gave similar results, except that fewer cases showed reduced expression. Statistical analysis of prolif- 


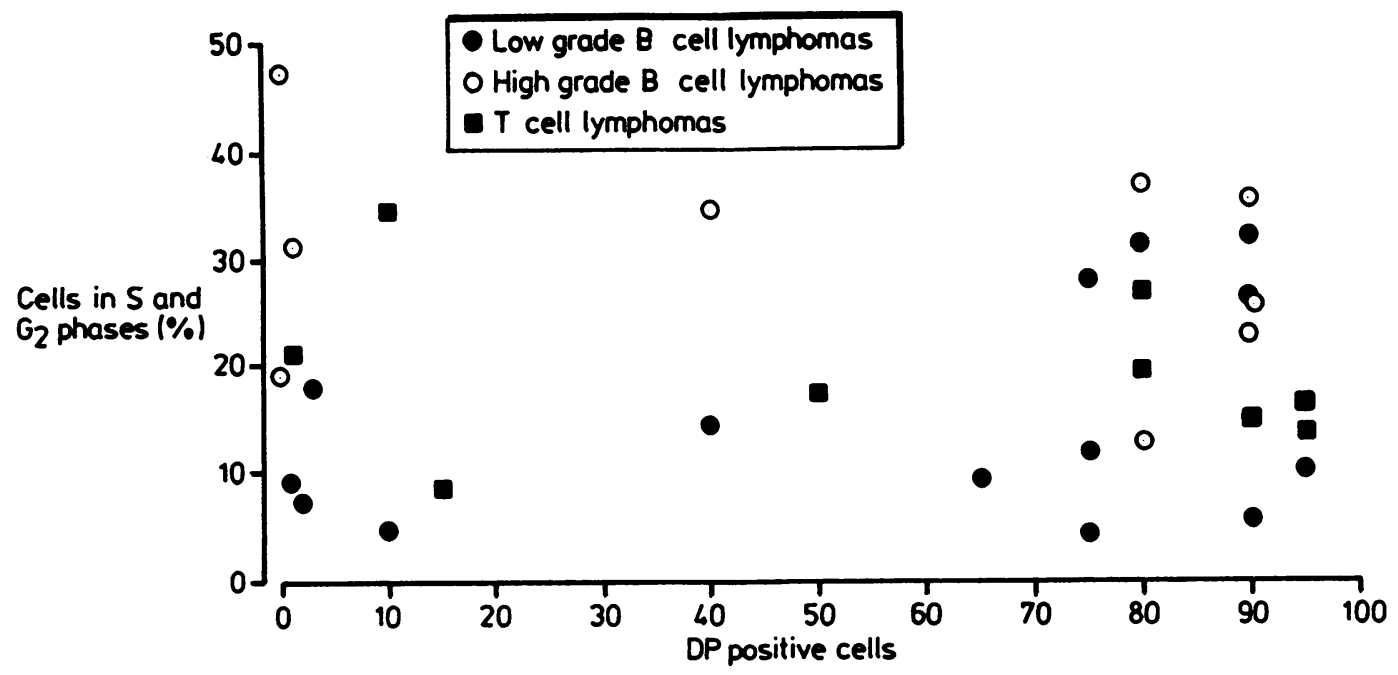

Fig 4 Percentage of cells in $S$ and $G_{2}$ phase $v$ percentage of DP positive cells.

eration indices in relation to non-coordinate and coordinate expression of MHC class II subregion products did not show significant differences (Student's $t$ test, $\mathrm{p}>0.5$ ).

The mean proliferation index of high grade $B$ cell lymphomas was $29 \%$ compared with $15 \%$ for low grade B cell lymphomas. The mean proliferation index of $\mathrm{T}$ cell lymphomas $(19 \%)$ was of intermediate value between high and low grade B cell lymphomas.

\section{Discussion}

In this study we have shown that MHC class II antigens are expressed by most $B$ and $T$ cell nonHodgkin's lymphoma. MHC class II antigen expression is a feature of all normal B lymphocytes, ${ }^{1}$ but it only occurs in normal $\mathrm{T}$ lymphocytes after activation. ${ }^{18}$ In their expression of $\mathrm{MHC}$ class II antigens $T$ cell lymphomas in this study resembled activated rather than non-activated $\mathrm{T}$ lymphocytes. Examples showing coordinate and non-coordinate expression of MHC class II subregion products were present within both $B$ and $T$ cell groups. Furthermore, patterns of non-coordinate expression were similar in both groups. Thus contrary to a previous suggestion, ${ }^{19}$ MHC class II antigen expression does not seem to be useful in distinguishing B cell from $T$ cell lymphomas. The present study supports the work of Weiss et $a,^{2021}$ who found that MHC class II antigen expression is common in mycosis fungoides and peripheral $\mathrm{T}$ cell lymphomas.

In showing that a substantial proportion of $B$ cell non-Hodgkin's lymphoma show non-coordinate expression of MHC class II subregion products, that DR antigens are strongly expressed in most cases, and that reduced DQ antigen expression is common, the results of this study agree with those with previous work. ${ }^{4}$ In the present study all cases that exhibited non-coordinate expression showed reduced DP expression, whereas reduced DP expression was a rare finding in the previous study. The reason for this difference is not readily apparent: it may reflect differences in the causation or nature of lymphomas in the two geographical regions as both studies used the same antibodies and similar immunostaining techniques.

The patterns of non-coordinate antigen expression were of interest. DP expression was always reduced and was associated in some cases with reduced DQ expression, and rarely, reduced DR expression. Thus only three patterns of non-coordinate expression were seen, and this may have a bearing on the mechanisms regulating the expression of the different subregion products. The results of the present study favour the view that these are interdependent and that the expression of DP depends on DQ, which, in turn depends on DR. If this is not true study of further lymphomas should indicate cases with different patterns of non-coordinate expression, such as, for example, reduced DR and strong DQ and DP expression. None of the lymphomas we studied has shown such phenotypes.

It has also been suggested that the expression of MHC class II antigens in B cell leukaemias may be differentiation related. ${ }^{2}$ The variety of MHC class II antigen expression observed in the lymphoid malig- 
nancies studied here makes it unlikely that MHC class II antigen expression and tumour differentiation are closely linked.

Four of the MHC class II antigen antibodies used in this study-CR3.43, DA6.147, B7/21 and L243-showed no allotype restriction. Leu 10, however, does not detect DQ products present on homozygous DR3 and DR7 cells. ${ }^{9}$ Complete absence of staining with Leu 10 of both tumour and non-tumour cells should occur in cases with these genotypes. The complete absence of staining with Leu 10 occurring only in case 39 may therefore have resulted from failure of antibody to recognise $\mathrm{DQ}$ determinants rather than from a lack of DQ antigen. Similarly, the DR specific antibody DA6.164 does not recognise products present on homozygous DR7 cells. ${ }^{10}$ Antibody L243 (also DR specific but with no allotype restriction $^{9}$ ) was used in addition to DA6.164 when less than $50 \%$ of cells (grades 0,1 , or 2 ) were stained by DA6.164. L243 staining was able to confirm the presence or absence of DR antigens in this group of cases.

There are several possible explanations for the greatly increased expression of MHC class II antigens in the salivary gland epithelium adjacent to the centroblastic/centrocytic lymphoma seen in case 20 . It may represent an intrinsic epithelial cell response to physical infiltration by tumour cells, or the response of activated $\mathrm{T}$ lymphocytes within the lymphoma, or lymphoma cells themselves, with secretion of a $\gamma$-interferon like substance ${ }^{2223}$ and induction of MHC class II antigen expression.

Many observations suggest that MHC class II antigen expression in some cell types is related to cellular proliferation. Normal human B lymphocytes show increased MHC class II antigen expression during the $G_{0} / G_{1}$ transition and $G_{1}$ phase of the cell cycle. ${ }^{24}$ There is evidence to suggest that the interleukin II dependent proliferative response of $T$ lymphocytes requires $\mathrm{T}$ cell $\mathrm{MHC}$ class II antigen expression ${ }^{25} 26$ : the proliferation centres of B cell lymphocytic lymphoma show increased mitotic activity and increased MHC class II antigen expression. ${ }^{17}$

Finally, it has been suggested that MHC class II antigen expression may be influenced by differences in the proliferative activity of low grade and high grade B cell lymphomas. ${ }^{3}$ In this study no direct relation between the percentage of lymphoma cells expressing DP, DQ, and DR antigens and the cellular proliferation index assessed by flow cytometry was found. Moreover, no significant relation was established between the proliferation index of cases showing coordinate or non-coordinate expression of MHC class II subregion products. Indeed, a wide range of proliferation indices was seen in both groups, and case 28 , with no detectable MHC class II antigen expression, had a proliferation index of $31 \%$. MHC class II antigen expression, therefore, cannot be used as a marker of cellular proliferation.

In conclusion, the results of this study indicate that MHC class II antigen expression in non-Hodgkin's lymphoma does not help to distinguish tumours of B and $T$ cell lineage. Non-coordinate expression of the products of the MHC class II subregions-DP, DQ, and DR - often occurs in non-Hodgkin's lymphoma. Furthermore, the three patterns of non-coordinate expression observed suggest the expression of the subregion products is interdependent. Finally, noncoordinate expression does not show any relation to lymphoma differentiation or to proliferation index.

This work was supported by a grant from the Yorkshire Cancer Research Campaign. We are grateful to Drs CM Steel and K Guy for advice and the gift of monoclonal antibodies.

\section{References}

1 Nunez G, Giles RC, Ball EJ, Hurley CK, Capra JD, Stastny P. Expression of HLA-DR, MB, MT and SB antigens on human mononuclear cells: identification of two phenotypically distinct monocyte populations. J Immunol 1984;133:1300-6.

2 Guy K, van Heyningen V. An ordered sequence of expression of human MHC class-II antigens during B-cell maturation? Immunology Today 1983;4:186-9.

3 Krajewski AS, Guy K, Dewar AE, Cossar D. Immunohistochemical analysis of human MHC class II antigens in Bcell non-Hodgkin's lymphomas. J Pathol 1985;145:185-94.

4 Guy K, Krajewski AS, Dewar AE. Expression of MHC class II antigen in human B-cell leukaemia and non-Hodgkin's lymphoma. Br J Cancer 1986;53:161-73.

5 Lauder I, Bird CC, Child JA, Grigor I. Surface membrane phenotypic expression and treatment response of malignant lymphomas. J Pathol 1985;145:259-68.

6 Sunderland CA, Naiem M, Mason DY, Redman CWG, Stirrat GM. The expression of major histocompatibility antigens by human chorionic villi. J Reprod Immunol 1981;3:323-31.

7 Guy K, van Heyningen V, Cohen BB, Deane DL, Steel CM. Differential expression and serologically distinct subpopulations of human Ia antigens detected with monoclonal antibodies to Ia alpha and beta chains. Eur J Immunol 1982;12:942-8.

8 Watson AJ, DeMars R, Trowbridge IS, Bach FH. Detection of a novel human class II HLA antigen. Nature 1983;304:358-61.

9 Brodsky FM. A matrix approach to human class II histocompatibility antigens: reactions of four monoclonal antibodies with the products of nine haplotypes. Immunogenetics 1984;19:179-84.

10 Van Heyningen V, Guy K, Newman R, Steel CM. Human MHC class II molecules as differentiation markers. Immunogenetics 1982;16:459-69.

11 Lampson LA, Levy R. Two populations of Ia-like molecules on a human B-cell line. $J$ Immunol 1980;125:293-9.

12 Lennert K. Malignant Lymphomas other than Hodgkin's Disease. Handbuch der speziellen pathologischen Anatomie und Histologie. Berlin: Springer-Verlag, 1978:92.

13 Quirke P, Fozard JBJ, Dixon MF, Dyson JED, Giles GR, Bird CC. DNA aneuploidy in colorectal adenomas. Br J Cancer 1986;53:477-81. 
14 Hedley DW, Friedlander ML, Taylor IW, Rugg CA, Musgrove EA. Method for analysis of cellular DNA content of paraffin-embedded pathological material using flow cytometry. J Histochem Cytochem 1983;31:1333-5.

15 Hiddemann W, Schumann J, Andreeff M, et al. Convention on nomenclature for DNA cytometry. Cytometry 1984;5:445-6.

16 Bagwell CB. University of Miami School of Medicine, Miami, Florida. 1979. (Thesis.)

17 Swerdlow SH, Murray LJ, Habeshaw JA, Stansfeld AG. Lymphocytic lymphoma/B-chronic lymphocytic leukaemia-an immunohistopathological study of peripheral B lymphocyte neoplasia. Br J Cancer 1984;50:587-99.

18 Reinherz EL, Kung PC, Pesando JM, Ritz J, Goldstein G, Schlossman SF. Ia determinants on human T-cell subsets defined by monoclonal antibody: activation stimuli required for expression. J Exp Med 1979;150:1472-82.

19 Epenetos AA, Bobrow LG, Adams TE, Collins CM, Isaacson PG, Bodmer WF. A monoclonal antibody that detects HLA-D region antigen in routinely fixed, wax embedded sections of normal and neoplastic lymphoid tissues. J Clin Pathol 1985;38:12-17.

20 Weiss LM, Wood GS, Warnke RA. Immunophenotypic differences between dermatopathic lymphadenopathy and lymph node involvement in mycosis fungoides. Am J Pathol 1985;120:179-85.

21 Weiss LM, Crabtree GS, Rouse RV, Warnke RA. Morphological and immunologic characterisation of 50 peripheral T-cell lymphomas. Am J Pathol 1985;118:316-24.

22 Pober JS, Collins T, Grimbrone MA, et al. Lymphocytes recognise human vascular endothelial and dermal fibroblast Ia antigens induced by recombinant immune interferon. Nature 1983;305:726-9.

23 Shaw ARE, Chan JKW, Reid S, Seehafer J. HLA-DR synthesis induction and expression in HLA-DR negative carcinoma cell lines of diverse origins by Interferon- $\gamma$ but not by Interferon- $\beta$. JNCI 1985;74:1261-7.

$24 \mathrm{Kehrl}$ JH, Muraguchi A, Fauci AS. The modulation of membrane Ia on human B lymphocytes. Cell Immunol 1985;92:391-403.

25 Moretta A, Accolla RS, Cerottini JC. IL-2-mediated cell proliferation in humans is blocked by a monoclonal antibody directed against monomorphic determinants of HLA-DR antigens. J Exp Med 1982;155:599-604.

26 Effros RB, Dillard L, Zeller E, Naeim F, Walford RL. Strong HLA-DR expression in T cell cultures after activation is necessary for IL-2-dependent proliferation. Hum Immunol 1983;8:249-54.

Requests for reprints to: Dr MEF Smith, Histopathology Unit, 35-43 Lincoln's Inn Fields, London WC2A 3PN, England. 